\title{
CCDC6/PDGFRB Fusion Gene
}

National Cancer Institute

\section{Source}

National Cancer Institute. CCDC6/PDGFRB Fusion Gene. NCI Thesaurus. Code C99514.

A fusion gene that results from a chromosomal translocation $t(5 ; 10)(q 33 ; q 21)$ which fuses the 5' part of the CCDC6 gene with the 3' part of the PDGFRB gene. This gene fusion is associated with chronic myelomonocytic leukemia. 